the field of nutrition]. New learning technologies. Vol. 40, p. 289. [in Ukrainian].

10. Sylkin, O. O. (2011). Zmist terminu "profesiino znachushchi yakosti osobystosti" i tekhnolohiia vyznachennia tsykh yakostei dlia okremoho fakhivtsia [The content of the term "professionally meaningful personality traits" and the technology of identifying these qualities for a particular specialist]. Scientific works. Series: Pedagogy, Psychology and Sociology. Vol. 9 (191), Donetsk: DVNZ “DonNTU”.[in Ukrainian].

11. Fedorenko, M. V. (2007). Do problemy vyznachennia profesiino znachushchykh yakostei pedahoha [To the problem of determining the professionally significant qualities of the teacher]. Problems of modern pedagogical education. Part. 2, vol . 15, Yalta, pp.111-118. [in Ukrainian].

12. Chaban, N. I. (2003). Kharakterystyka poniattia "dilova liudyna" ta yii yakostei u suchasnykh doslidzhenniakh [Characteristics of the concept "business man" and its qualities in modern research]. Taurian Journal of Education, no.1, pp.15-16. [in Ukrainian].

13. Shulha, V.V.(2005). Osoblyvosti formuvannia profesiino vazhlyvykh yakostei psykholohiv osvity v zalezhnosti vid stazhu roboty [The features of formation of professionally important qualities of psychologists of education depending on the length of work]. Scientific notes of Hryhoriy Kostyuk Institute of Psychology of the Academy of Pedagogical Sciences of Ukraine. Kyiv:Hlavnyk, issue. 26, vol 4, pp.499-508. [in Ukrainian].

Стаття надійшла до редакції 26.10.2018

УДК 378.018.8:33 - 051]:340.12

DOI:

Свген Підлісний, здобувач Уманського державного педагогічного університету імені Павла Тичини

\title{
МОДЕЛЬ ФОРМУВАННЯ ПРАВОВОЇ КУЛЬТУРИ МАЙБУТНІХ БАКАЛАВРІВ ЕКОНОМІКИ
}

У статті обтрунтовано модель та розкрито ї̈ структуру. Встановлено, щчо до методологічно-иільового блоку входить: мета, методологічні підходи та принципи, змістово-організаційного: етапи, зміст, методи, форми, засоби, результативного-оцінного: критерії, показники, рівні та результат. Кожен з компонентів моделі покликаний вирімувати певну частину загального педагогічного завдання - формування правової культури студентів. Доведено, щүо обтрунтована модель є описовим аналогом процесу формування правової культури студентів і відображає формалізовані $і$ аналітичні конструкиії їі найважливіших характеристик.

Ключові слова: модель; прочес; аналог; правова культура; формування правової культури; майбутні бакалаври економіки.

Jim. 8.

Yevhen Pidlisniy, Applicant

Uman Pavlo Tychyna State Pedagogical University

\section{MODEL OF FORMATION OF LEGAL CULTURE OF FUTURE BACHELORS OF ECONOMIC}

The article substantiates the model and reveals its structure. It is established that the model of legal culture of the future bachelors of economics is a descriptive analogue of the process of formation of the legal culture of students and reflects the formalized and analytical constructions of its most important characteristics of a prognostic nature. It is disclosed that the model of formation legal culture of future bachelors of economics is an integral unity of mutually interconnected, interconnected and dynamically interacting components of the educational process in the educational process: the methodological-target (educational goal (formation of the legal culture of future bachelors of economics), methodological approaches (systemic, culturological, personality oriented, axiological, activity approaches) and principles that ensure its transformation into organizational and methodical elements), content-organizational (stages (adapt purpose-oriented (criterion (motivational-value, cognitive-informational, activity-behavioral), level (high, medium, and high-level), methodological and organizational forms, means, technologies) low) the formation of the legal culture of future bachelors of economics, the result, requirements to the level of formation of the student's legal culture that are necessary and sufficient for future professional activity, assessment of the work on analytical and experimental study of the the process of formation of the legal culture of future bachelors of economics). It is established that each component of the model, having its own function, specific content and methodical features, is intended to solve a certain part of the general pedagogical task - the formation of the legal culture of students.

It is proved that such a structure of the model of formation of the legal culture of future bachelors of the economy in the process of professional training in higher education institutions fits into the modern way of interpreting 
economic education as a process of formation of the creative personality of a modern economist and the professional readiness for the implementation of legal relations.

Keywords: a model; a process; analog; legal culture; a formation of legal culture; the future bachelors of economics.

П остановка проблеми. Проблема вдосконалення підготовки майбутніх бакалаврів економіки актуальна вже в силупрагнення освітньої системи задовольняти вимоги динамічного суспільства, де особливе місце займає правова культура. Для ії розробки розкрито вимоги суспільства до їх підготовки, серед яких: соціальний запит (необхідність високого рівня правової культури, правової свідомості для інтеграції в (С), академічні вимоги підготовки фахівців, орієнтовані на перспективу (знання перспективного розвитку професійної сфери, що полягає у гармонізації українського та європейського законодавства), соціальне замовлення на підготовку висококваліфікованих спеціалістів з високим рівнем правової культури (вимоги роботодавців, потреби людей в освіті).

Зростаючий інтерес в педагогічній науці до побудови “моделі сучасного фахівця" в різних сферах професійної діяльності, обумовлений зміною суспільних і педагогічних парадигм, актуалізуе вивчення методології цього моделювання 3 метою виявлення найбільш оптимальних підходів до подальшої розробки моделі правової культури майбутніх бакалаврів економіки.

Аналіз основних досліджень. Проблема проектування моделі фахівця, в тому числі бакалавра представлена в цілому ряді наукових робіт, які носять як теоретичний, так і прикладний характер А. Горстко, Л. Капченко, Є. Лодатко, А. Семенова, В. Штофф.

Проблему розробки моделі професійної підготовки майбутніх економістів та формування у них правової культури характеризують Н. Боярчук, С. Василина, В. Велігон, І. Власюк, А. Максименко, С. Мальона, Г. Чубрина та ін.

Н. Боярчук трактує моделювання процесу формування професійної компетентності майбутніх економістів як дослідження алгоритму зміни чинної педагогічної реальності завдяки встановленню чітких зв'язків між сутнісними (понятійними, концептуальними, процесуальними) характеристиками цього процесу, окремими аспектами освітнього процесу й особливостями економічної діяльності на різних рівнях соціокультурного простору $[1,89]$.

Модель правової підготовки учнів ПТНЗ, яку розроблено С. Василиною, відображає розгорнутий у часі педагогічний процес, побудований на засадах цілісного підходу до розвитку правової особистості як вищої цінності й мети педагогічної діяльності, що реалізується шляхом раціонального поєднання ефективних освітніх технологій і природного прагнення особистості до саморозвитку та самореалізації [2, 95].

Під моделлю формування професійнотермінологічної компетентності майбутніх бакалаврів економіки І. Власюк розуміє цілісний педагогічний процес, в якому сукупність підходів, форм, методів, засобів і створення відповідних педагогічних умов спрямовані на набуття студентами грунтовних знань економічної, фахової термінології, умінь і навичок ї̈ доцільного використання, а також розвиток особистості студента як майбутнього учасника професійної діяльності [3, 52].

Пропонована модель формування правової культури А. Максименко, охоплює весь процес правової освіти та правового виховання від набуття правових знань, умінь, навичок, розвитку ціннісно-правової спрямованості особистості студента, правових поглядів, уявлень, мотивів, правових установок, ціннісних орієнтацій ставлення до закону як до цінності, до прояву правової культури в правомірній поведінці і соціально-правовій активності студентів [8].

Аналіз проектованих моделей професійної підготовки майбугніх економістів та формування у них правової культури показав, що в загальному така модель $є$ динамічною, структурнофункціональною і охоплює процес від набуття знань про проектування інтересів, мотивів, ціннісних орієнтацій, навичок, умінь, до прояву правової культури в поведінці і діяльності.

Мета статті - обгрунтувати модель формування правової культури майбутніх бакалаврів економіки та розкрити ії структуру.

Виклад основного матеріалу. Модель правової культури майбугніх бакалаврів економіки $\epsilon$ описовим аналогом процесу формування правової культури студентів і відображає формалізовані і аналітичні конструкції ii найважливіших характеристик, носить прогностичний характер. Кожен з компонентів моделі, маючи свою функцію, специфічний зміст і методичні особливості, покликаний вирішувати певну частину загального педагогічного завдання формування правової культури студентів.

У зв'язку з вищесказаним модель формування правової культури майбугніх бакалаврів економіки $\epsilon$ цілісною єдністю взаємообумовлених, взаємозв'язаних і динамічно взаємодіючих в освітньомупроцесіскладників-блоків: методологічно- 
цільового (освітня мета, методологічні підходи та принципи, що забезпечують ії трансформацію в організаційно-методичні елементи), змістовоорганізаційного (етапи, зміст, методи i організаційні форми, засоби), результативногооцінного (критерії, показники, рівні, результат, вимоги до рівня сформованості правової культури студента, що $є$ необхідними та достатніми для майбутньої професійної діяльності, оцінка роботи 3 аналітичного та експериментального вивчення процесу формування правової культури майбутніх бакалаврів економіки).

Для побудови моделі передусім необхідно обгрунтувати мету та завдання моделювання. Мета в загальнонауковому сенсі розуміється як один з елементів поведінки, безпосередній мотив свідомої діяльності, що характеризується передбаченням в свідомості результату діяльності і способів його досягнення. Таким чином, взаємозв'язок мети і результату закладений в самому визначенні мети. Ця обставина передбачає наявність зворотного зв'язку. Цілеспрямована педагогічна діяльність призводить до результатів, причому процес їх досягнення виглядає циклічно, відбувається до тих пір, поки не вирівняються відмінності між метою і результатом [7, 48].

Мета моделювання випливає з існуючого на сучасний момент соціального замовлення професійної освіти: сформованості правової культури майбутніх бакалаврів економіки, що забезпечує їм готовність до реалізації правових аспектів у майбутній професійній діяльності.

Отже, метою моделі $є$ формування правової культури майбутніх бакалаврів економіки.

Розроблена нами модель спрямована на реалізацію таких основних завдань: формування цінностей, мотивів і потреб, установок і смислів студентів по відношенню до економічної діяльності, формування правових знань в галузі економіки, формування умінь і навичок студента по реалізації правових аспектів в економічній діяльності.

Суб'єктами в моделі виступають педагоги освітнього закладу і студенти.

Для розробки моделі формування правової культури майбутніх бакалаврів економіки вважаємо необхідним використати системний, культурологічний, особистісно-орієнтований, аксіологічний, діяльнісний підходи.

Досить цікавим є погляд Т. Кругоус на ієрархію методологічних підходів: особистісноорієнтований підхід $\rightarrow$ оволодіння змістом навчання має відбуватись у процесі спеціально організованої діяльності, діяльнісний підхід $\rightarrow$ сформованість певного рівня фахової компетентності має бути результатом спеціально організованої професійної підготовки майбутнього фахівця (компетентнісний підхід) [6, 30].

Методологія системного підходу, філософські аспекти дослідження систем представлені в роботах вітчизняних і зарубіжних вчених (С. Бондаренко, В. Велігон, М. Каган, Н. Ржевська, Е. Юдін), що дозволило розглядати процес формування правової культури майбутніх бакалаврів економіки як цілісну систему, яка створена взаємодією iї складників.

Авторами визнається велика науковопрактична роль системного підходу в сучасній науці. Сьогодні системний підхід розглядається як єдиний загальнонауковий методологічний напрям, який ставить своїм завданням розробку принципів, методів і засобів вивчення об'єктів, що становлять систему.

У нашому дослідженні системний підхід охоплює всі основні сторони досліджуваного процесу від постановки цілей, мотивації і конструювання освітнього процесу до перевірки ефективності роботи нових освітніх систем, їх апробування та поширення.

Отже, в рамках системного підходу розглядаємо процес формування правової культури майбутніх бакалаврів економіки у вигляді системи.

Культурологічний підхід (М. Бабаєв, Є. Бугачевська, Е. Ільєнков, А. Кармін, Н. Смєлова) дозволяє забезпечити процес формування правової культури майбутніх бакалаврів економіки шляхом входження студента в правову культуру економічної діяльності за допомогою активного освоєння основних її елементів: правових знань, умінь, ціннісних орієнтирів, вироблення певних поглядів і переконань.

Специфіка цього підходу полягає в гармонізації духовного світу особистості в процесі оволодіння правовою інформацією; в здатності до соціальноправової адаптації в динамічно мінливих економічних і політичних умовах; в самостійності інтерпретації отриманої правової інформації.

Переваги такого підходу в тому, що він дозволяє вивчити правові проблеми економічної діяльності комплексно, у взаємозв'язку 3 багатьма факторами і явищами; гостріше усвідомити необхідність комплексного вирішення нагромадженого у взаємозв'язках бізнесу 3 правом і етикою, розробити системузаходів щодо удосконалення правового забезпечення економічної діяльності, повернення довіри до неї з боку населення; глибше розкрити і усвідомити 
позитивну роль економічної діяльності, іiї місце і значення для суспільства і кожної людини.

В рамках особистісно-орієнтованого підходу дослідники (Р. Андрусишин, Г. Балл, Л. Дибкова, Ж. Жумагазіна, Л. Максимова, Г. Чубрина) в якості основи використовують модель діяльності фахівців, виділяючи в ній базові компоненти: проблеми (завдання), які доводиться вирішувати фахівцю в професійній діяльності; типи діяльності, тобто способи або прийоми, за допомогою яких вирішуються сформульовані завдання, функції, узагальнені характеристики основних обов'язків, що виконуються відповідно до вимог професії, шляхи вирішення виділених проблем або завдань, знання теоретичного або прикладного характеру, якими оперує у своїй діяльності фахівець, вміння і навички, за допомогою яких досягаються бажані результати, якості особистості, що забезпечують успішність дій в обраній сфері, ціннісні орієнтації та установки.

Такий підхід забезпечує свободу вибору змісту освіти з метою задоволення освітніх, духовних, культурних і життєвих потреб особистості, можливості самоорганізації в культурноосвітньому просторі $[4,61]$.

В нашому дослідженні ми виходили з тих позицій особистісно-орієнтованого підходу, що тільки в тому випадку, коли майбутній бакалавр розглядається як цілісна особистість 3 психічними установками, а освітній процес спрямований на актуалізацію потенціалу, створюються умови для розвитку розумових, творчих здібностей, формується вміння приймати оптимальні рішення в непередбачуваних обставинах.

Серед провідних методологічних підходів до формування правової культури майбутніх бакалаврів економіки науковці (В. Боер, І. Бех, В. Басай, С. Василина) виокремлюють аксіологічний, який на їх думку спрямований на створення умов для набуття студентом сенсів своєї діяльності в діалозі з соціумом і культурою. Це, на наш погляд, сприяє становленню особистісного сенсу, усвідомленню особистого досвіду, формуванню відповідної позиції до професійної економічної діяльності.

У цьому підході правова культура сприймається як система правових цінностей, створених і створюваних під час розвитку суспільства та таких, що містять у собі передові досягнення правової культури людства.

Відповідно до поглядів прихильників аксіологічного підходу основними індикаторами сформованості правової культури особистості виступають: а) правова обізнаність (ступінь відповідності між уявленнями людей про правильну в правовому сенсі поведінку, з одного боку, і законом, з другого); б) правова активність (ступінь фактичної участі людей в ситуаціях, регульованих цивільним законодавством); в) перевага правових або неправових процедур (відповідність дій, які реально або умоглядно обираються респондентом для вирішення своїх проблем); г) визнання або невизнання цінності права (уявлення про допустимість виходу за межі правового поля).

Ідея діяльнісного підходу (Г. Атанов, М. Каган, А. Леонтьєв, С. Рубінштейн та ін.) пов'язана не тільки 3 самою діяльністю і механізмами становлення правової культури особистості, скільки $з$ діяльністю як засобом становлення і розвитку суб' єктності людини в динаміці особистісного розвитку в умовах соціальних змін.

Сутність і цінність цього підходу для нашого дослідження в тому, що він постулює ідеї формувального і розвивального призначення діяльності, ідеї моделювання в навчанні; передбачає допомогу бакалавра в усвідомленні себе суб'єктом соціально-економічного досвіду, в його самореалізації та самоствердженні. Діяльнісний підхід забезпечує цілісний погляд на освітній процес; передбачає активність студента в умовах конкретних ситуацій, при цьому в умовах структури економічних знань, коли не все можна продемонструвати, важливого значення набуває розвиток самостійності, здатності шляхом живого споглядання і подальшого абстрагування виділяти корисне для практичної економічної діяльності.

У процесі формування правової культури майбутніх бакалаврів економіки використовуються загальнонаукові принципи, проте в цій галузі вони набувають специфічного змісту.

Становлення правової держави має базуватися на законних методах економічного зростання. Важливе значення набуває філософське і логічне осмислення громадянином економічних процесів в державі, оволодіння методами економікоправового переконання. У зв'язку з цим, набуває актуальності принцип раціональності. Це означає здатність до здійснення раціональних дій у виконанні службових обов'язків, застосування правозахисних заходів впливу на економічні відносини.

Принцип свідомості виявляється не тільки в усвідомленні змісту навчального матеріалу, а й в правильному розумінні значення мети формування правової культури. Він полягає в цілеспрямованому активному сприйнятті досліджуваних явищ, їх осмислення і творчій переробці, застосуванні. Практична реалізація принципу свідомості 
здійснюється шляхом дотримання правил: перевірки його корисності для життя бакалавра, його майбутньої діяльності, щоб він розумів що, чому і як потрібно робити, попередньо глибоко їх усвідомивши. Принцип свідомості передбачає здатність бакалавра правильно висловлювати думки в словах, діях, позитивне і зацікавлене ставлення студента до досліджуваного явища, ступінь самостійності дій чим вона вища, тим свідоміше засвоюються знання.

Принцип відкритої позиції. Ставлення до студентів як до рівнозначних учасників суб' єктсуб'єктної взаємодії сприяє отриманню знання, яке будується у спільній діяльності викладача і студента. Цей принцип означає готовність бакалавра не тільки слідувати разом 3 викладачем до надання і отримання професійних економічних знань, а й створює передумови для довірчих відносин, знімає наліт відчуженості в міжсуб'єктній взаємодії. Принцип передбачає здатність суб' єктів правових відносин, по-перше, до сприйняття правової культури як професійної цінності, по-друге, до розвитку власних цілей у взаємозв'язку економічної діяльності і правової культури.

Принцип діалогової взаємодії заснований на тому, що діяльність суб'єкта освітньої діяльності обумовлена діалоговою природою процесів навчання і спілкування. Значення цього принципу для нашого дослідження у тому, що він відіграє важливу роль в розвитку суб'єктної позиції бакалавра; ми прагнули навчити його знаходити i відстоювати свою точку зору, свою власну думку. Важливо, щоб ця думка мала під собою серйозну теоретичну базу. Реалізація цього принципу передбачає насиченість змісту навчального матеріалу правовим матеріалом, інтерпретацію економічного знання в формі діалогу, подолання вузького розуміння діалогу як спору і заміщення його розумінням такого як прагнення до знаходження істини, згоди.

Принцип цивілізованості економічної діяльності та правової культури студента означає, що правові рішення в галузі економіки повинні прийматися на досить високому професійному рівні. Соціальна взаємодія суб'єктів права в сфері економіки вимагає грунтовного знання новітніх економічних реформ і технологій.

Другим складником-блоком моделі формування правової культури майбутніх бакалаврів економіки $\epsilon$ змістово-організаційний, до якого входять: етапи, зміст, методи і організаційні форми, засоби, технології.

Процес формування правової культури майбутніх бакалаврів економіки проходить ряд етапів: адаптаційно-мотиваційний, розвивально- операційний, професійно-орієнтований.

Метою першого етапу є розвиток позитивної мотивації освітньої діяльності, захопленості професією, стимулювання. У зміст цього етапу ввійшли такі змістові характеристики: виявлення чинників, що визначають необхідність ефективної правової підготовки майбутніх фахівцівекономістів, особливостей їх роботи в умовах ринку, діагностика рівня сформованості правової культури майбутніх бакалаврів економіки, мотивація до отримання економічної професії, осмислення технології викладання правових дисциплін, спрямованої на розуміння сутності праці економіста в динамічно змінних умовах, що вимагає відповідальності, вміння працювати в колективі, здатність ставити, знаходити різні правові варіанти вирішення проблеми. Як результат першого етапу: спрямування ціннісної орієнтації на професію економіста, виявлення реального рівня правової культури як основи для отримання економічної професії.

Другий етап - розвивально-операційний здійснювався 3 метою набуття досвіду формування правових відносин у освітній діяльності майбутнього економіста. Під час цього етапу його змістом були: освоєння норм, цінностей, зразків, умінь здійснення економіко-правової діяльності у освітньому процесі, активна включеність студентів в різноманітні види аудиторної та позааудиторної діяльності. Як результат другого етапу сформованість у бакалавра економічних і правових знань і умінь.

Третій етап - професійно-орієнтований проходив 3 метою оцінки діяльності та вдосконалення особистісних якостей (правове мислення, правові вміння, готовність до використання правових знань). Зміст етапу: повторна діагностика для виявлення рівня сформованості правової культури бакалавра; забезпечення модернізації діяльнісних правових норм, знань, рефлексія власної діяльності в кінці кожного нововведення, вдосконалення використання інноваційних методів проектування при вивченні економічних дисциплін. Результат: сформований високий рівень правової культури у майбутніх бакалаврів економіки, здатність здійснювати правову професійну діяльність i рефлексувати результати цієї діяльності.

Упровадження моделі формування правової культури майбугніх бакалаврів економіки можливо лише на основі конкретного змісту. Вважаємо, що цей складник моделі є системотвірним. Через його використання має найвиразніше проглядатися процес і результат формування правової культури майбутніх бакалаврів 
економіки.

На думку А. Загородньої зміст економічної освіти залежить від поставленої мети та цілей навчання, економічної політики держави, завдань, які постають перед економікою, системи економічної освіти студентів, наявності у закладах вищої освіти матеріальної бази для опанування студентами економічних знань, викладацької майстерності, взаємозв'язку освітнього процесу відповідно до потреб держави [5].

Під змістом формування правової культури майбутніх бакалаврів економіки упроцесі фахової підготовки розуміємо сукупність економічних та правових знань, умінь та навичок, норм поведінки, цінностей, ідей та ідеалів, елементів матеріальної і моральної складової соціуму, спрямованих на формування правової культури, які підлягають засвоєнню і перетворенню в індивідуальний внутрішній світ.

Зміст освіти включає дисципліни відповідних циклів та спрямовується на формування критеріїв правової культури: мотиваційно-ціннісного (спрямований на формування відповідальності і впевненості, відданості принципу верховенства права, гуманності, чесності та поваги до людей при здійсненні економічної діяльності), когнітивноінформаційного (формує такі якості майбутнього фахівця, як динамічність, здатність приймати рішення на основі правопорядку, усвідомлення, глибина, активність правової діяльності), діяльнісно-поведінкового (спрямований на формування таких якостей, як активність, здатність до побудови правових дій).

Зважаючи на зміст та етапи формування правової культури майбутніх бакалаврів економіки нами підібрані відповідні методи та організаційні форми для активізації зазначеного процесу. До форм освітнього процесу віднесено: традиційні (лекції, семінари; практичні заняття; лабораторнопрактичні заняття; самостійна робота, науковопрактичні та методичні конференції, виробнича практика) та інноваційні (лекція-бесіда, бінарна лекція, проблемна лекція, лекція-консультація, лекція-прес-конференція, співбесіда, тренінги, індивідуальний практикум, зустрічі з працівниками правоохоронних органів, тематичні вечори, консультації-співбесіди, конкурси, громадські перегляди фільмів, вистави, телепрограми, індивідуальний освітній маршрут, створення бізнес-проекту, модерація, включення в різноманітні види правозастосовчої діяльності), активних методів (проблемний метод, вирішення практичних завдань, вправ, складання правових документів, “портфоліо”, метод “право на питання”, кейс-стаді, моделювання конкретних правових ситуацій (проблемні семінари), тематичні дискусії, “круглий стіл”, дебати, діалоги, метод правотворчості; “мозковий штурм”, складання правових документів), педагогічних технологій (диференційоване навчання, проблемного навчання, модульна, проектна, ігрова).

Для формування стійкого інтересу до процесу формування правової культури пропонуємо чергування форм і методів навчання; показ практичного застосування знань у зв'язку з життєвими планами і орієнтаціями студентівекономістів та виділяємо такі засоби навчання: електронний підручник, застосування мультимедіасистем і інтерактивних комп'ютерних засобів; електронний бібліотечний каталог, локальні і глобальні обчислювальні системи, електронна пошта, система телеконференцій, контроль знань за допомогою тестуючих комплексів.

Результативний блок моделі включає критерії (мотиваційно-ціннісний, когнітивно-інформаційний, діяльнісно-поведінковий) та рівні (високий, середній, низький) сформованості правової культури майбутніх бакалаврів економіки.

Результатом апробації моделі є сформована правова культура майбутніх бакалаврів економіки в закладах вищої освіти.

Така структура моделі формування правової культури майбугніх бакалаврів економіки у процесі фахової підготовки в закладах вищої освіти вписується в русло сучасного трактування економічної освіти як процесу формування творчої особистості сучасного економіста і його професійної готовності до здійснення правових відносин.

Висновки. Отже, нами розроблена модель формування правової культури майбутніх бакалаврів економіки, яка охоплює такі блоки та їх складники: методологічно-цільовий (мета, підходи, принципи), змістово-процесуальний блок (етапи, зміст, форми, методи, технології, засоби), оцінно-результативний блок (критерії, показники, рівні, відповідний результат), що відображають специфіку формування правової культури майбутніх бакалаврів економіки у процесі фахової підготовки в закладах вищої освіти.

Перспективу подальших досліджень вбачаємо у апробації та експериментальній перевірці моделі формування правової культури майбутніх бакалаврів економіки.

\section{ЛІТЕРАТУРА}

1. Боярчук Н. Модель формування професійної компетентності майбутніх економістів. Педагогічні науки. - 2013. - № 1. - С. 85-95.

2. Василина С. І. Психолого-педагогічні умови 
правової підготовки учнів професійно-технічних навчальних закладів: дис. ... канд. пед. наук. Львів, 2017. 311 с.

3. Власюк I. В. Формування професійнотермінологічної компетентності майбутніх бакалаврів економіки в процесі вивчення фахових дисциплін: дис. ... канд. пед. наук. Вінниця, 2015. $272 \mathrm{c.}$

4. Жумагазина Ж. А. Социально-педагогическое проектирование учебной деятельности бакалавра экономики: дисс. ... канд. пед. наук. - Оренбург, 2010. - 190 с.

5. Загородня А. А. Зміст професійної підготовки фахівців економічної галузі в Україні. Innovative solutions in modern science. 2016. Vol. 7, No. 7. URL: http://naukajournal.org/index.php/ IS MSD/article/view/970/1107(accessed: 18.07.2018).

6. Крутоус Т. П. Формування фахової компетентності майбутніх бакалаврів економіки у процесі навчання природничо-наукових дисциплін: дис. ... канд. пед. наук. Вінниця, 2015. $245 \mathrm{c}$.

7. Леонтьев А. Н. Деятельность. Сознание. Личность: учеб. пособ. - Москва: Смысл, 2004. $345 \mathrm{c}$.

8. Максименко А. А. Модель формирования правовой культуры студентов колледжа в процессе профессионального образования. Современная наука: Актуальные проблемы теории и практики. Серия: Гуманитарные науки. 2012. № 2. URL: http://www.vipstd.ru/nauteh/ index.php/ru/-gn12-02/411-a (дата обращения: 17.07.2018).

\section{REFERENCES}

1. Boiarchuk, N. (2013). Model formuvannia profesiinoi kompetentnosti maibutnikh ekonomistiv [Model of formation of professional competence of future economists]. Pedagogical science, no. 1, pp. 85-95. [in Ukrainian].

2. Vasylyna, S. I. (2017). Psykholoho-pedahohichni umovy pravovoi pidhotovky uchniv profesiino- tekhnichnykh navchalnykh zakladiv [Psychologicalpedagogical conditions of legal training of students of vocational schools]. Candidate's thesis. Lviv, 311 p. [in Ukrainian].

3. Vlasiuk, I. V. (2015). Formuvannia profesiinoterminolohichnoi kompetentnosti maibutnikh bakalavriv ekonomiky v protsesi vyvchennia fakhovykh dystsyplin [Formation of vocational and terminological competence of future bachelors of economics in the process of studying professional disciplines]. Candidate's thesis. Vinnytsia, 272 p. [in Ukrainian].

4. Zhumahazyna, Zh. A. (2010). Sotsialnopedagogicheskoe proektirovanie uchebnoy deyatelnosti bakalavra ekonomiki [Socio-pedagogical design of educational activities bachelor of economics]. Candidate's thesis. Orenburh, 190 p. [in Russian].

5. Zahorodnia, A. A. (2016). Zmist profesiinoi pidhotovky fakhivtsiv ekonomichnoi haluzi v Ukraini [Content of professional training of specialists in the economic sphere in Ukraine]. Innovative solutions in modern science. Vol. 7, No. 7. Available at: http:/ /naukajournal.org/index.php/ISMSD/article/view/970/ 1107 (accessed 18.07.2018). [in Ukrainian].

6. Krutous, T. P. (2015). Formuvannia fakhovoi kompetentnosti maibutnikh bakalavriv ekonomiky u protsesi navchannia pryrodnycho-naukovykh dystsyplin [Formation of professional competence of future bachelors of economics in the process of teaching natural sciences]. Candidate's thesis. Vinnytsia, 245 p. [in Ukrainian].

7. Leontev, A. N. (2004). Deiatelnost. Soznanye. Lychnost [Activity. Consciousness. Personality]. Tutorial. Moscow: Meaning, 345 p. [in Russian].

8. Maksimenko, A. A. (2012). Model formirovaniya pravovoy kultury studentov kolledzha $\mathrm{v}$ protsesse professionalnogo obrazovaniya [The model of formation of the legal culture of college students in the process of vocational education]. Modern science: Actual problems of theory and practice. Series: Humanities,no. 2. Available at: http://www.vipstd.ru/ nauteh/index.php/ru/—gn12-02/411-a (accessed 17.07.2018). [in Russian].

Стаття надійшла до редакції 17.10.2018

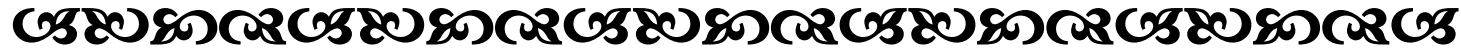

"Майдутнє - це не те, куди ми йдемо, а те, що ми створюємо. Фороги слід не шукати, а Будувати. Сам процес будівництва змінює яК самого твория, так і його долю”. Dжон Шаар вчений, політичний теоретик

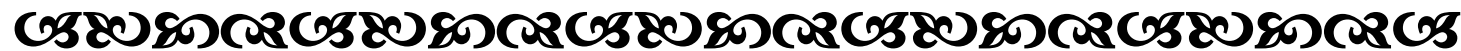

